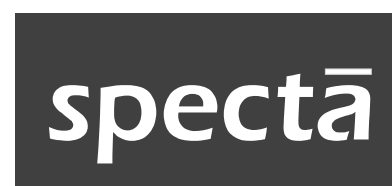

Journal of Photography, Arts, and Media

\title{
POTRET PEREMPUAN DAYAK IBAN, KAYAN, DESA, DAN SUNGKUNG DI KALIMANTAN BARAT
}

Rizqi

Mahendaradewa Suminto*

Pitri Ermawati**

Fakultas Seni Media Rekam, Institut Seni Indonesia (ISI) Yogyakarta

Surel: mahendrads@gmail.com

\begin{abstract}
Abstrak
Penciptaan karya fotografi ini bermaksud merekam identitas kebudayaan subsuku Dayak yaitu Dayak Iban, Kayan, Desa, dan Sungkung khususnya pada perempuan-perempuan Dayak yang masih memiliki dan menjalankan tradisi leluhur. Tradisi-tradisi leluhur yang dijalankan para perempuan Dayak yaitu memanjangkan daun telinga, bertato, memakai gelang besi, menenun, membuat kerajinan manik-manik, dan menganyam. Foto potret ini memunculkan masing-masing karakter subsuku Dayak dengan aspek-aspek fotografi potret meliputi penataan pose, ekspresi, porsi subjek, komposisi, cahaya, properti pendukung, latar belakang, lokasi pemotretan, dan kostum yang digunakan. Karya fotografi yang dihasilkan berupa foto potret dalam ranah dokumenter yang dapat menyampaikan realita sosial. Karya foto potret ini, diharapkan menjadi suatu peninggalan yang berharga untuk bangsa yang dapat digunakan untuk kembali mengingat dan melihat awal dari keberadaan sekarang.
\end{abstract}

Kata-kata kunci: potret, Dayak, Iban, Kayan, Desa, Sungkung, fotografi

\begin{abstract}
Women Portraits of Dayak Iban, Kayan, Desa, and Sungkungin Kalimantan Barat. The creation of this photographic work is meant to capture the cultural identity Sub-tribe of Dayak that is Iban, Kayan, Desa, and Sungkung. Particulary in woman of Dayak, who still keep and preserve the tradition. Ancestral tradition that is still held on Dayak women is lengthen the earlobe, make tattoo, wear iron bracelets, weave, craft beads, and make mats. This portrait brings each of Sub - tribe character of Dayak with aspects of photographic portrait which cover the pose structure, expression, portion of the subject, compotition, lighting, supporting property, background, shooting location, and costumes used. The creation of photographic work in the form of portraits under the domain of documentary which can deliver social reality. This portrait is expected to become a valuble legacy to the nation which can be used to recall and see the beginning of today's existence.
\end{abstract}

Key words: portrait, Dayak, Iban, Kayan, Desa, Sungkung, photography

\footnotetext{
*Dosen di Program Studi Animasi, Jurusan Film dan Televisi, Fakultas Seni Media Rekam, ISI Yogyakarta.

${ }^{*}$ Dosen di Program Studi Fotografi, Jurusan Fotografi, Fakultas Seni Media Rekam, ISI Yogyakarta.
} 


\section{PENDAHULUAN}

Perempuan merupakan makhluk yang lemah lembut dan penuh kasih sayang karena perasaannya yang halus. Diketahui sifat perempuan secara umum memiliki keindahan, kelembutan, rendah hati, dan melidungi (memelihara). Menurut Zaitun Subhan (2004: 1), perempuan berasal dari kata empu yang artinya dihargai, kemudian dijelaskan juga pergeseran istilah dari wanita ke perempuan. Kata wanita berasal dari bahasa Sansekerta, dengan dasar kata wan yang berarti nafsu sehingga kata wanita mempunyai arti dinafsui (diinginkan). Istilah kata perempuan lebih baik pemaknaannya yang sama artinya dengan kata puan merupakan sapaan hormat bagi kaum hawa yang berarti "orang yang dimuliakan atau yang dihormati”.

Suku Dayak memiliki berbagai peraturan untuk memagari kehormatan perempuan, bukan berarti membatasi gerak langkah perempuan, namun bagi suku Dayak perempuan sangat dimuliakan dan dihargai sehingga patut mendapatkan perhatian khusus berupa peraturan sebagai tujuan untuk perlindungan kaum perempuan. Peraturan tersebut memiliki hukuman bagi yang melanggar berupa denda, hal tersebut merupakan peraturan tidak tertulis turuntemurun dari leluhur yang tumbuh dan berkembang serta diyakini oleh masyarakat suku Dayak. Mereka memiliki norma-norma, ketentuan-ketentuan, dan peraturan-peraturan yang dipatuhi bersama sebagai suatu ikatan sehingga melahirkan sebuah identitas diri pada suku Dayak.

Istilah nama Dayak merupakan penyebutan nama yang oleh penduduk pesisir Kalimantan diberikan kepada penghuni pedalaman. Menurut Surjani Alloy (2008: 23), Kata Dayak berasal dari istilah Daya', Dyak, Dadjak, Dayaker, dan Dayak yang artinya "hulu" atau "pedalaman". Suku Dayak merupakan salah satu suku asli yang mendiami pulau Kalimantan selain suku Melayu dan Cina. Kelompok suku Dayak yang bermukim di ujung hulu sungai hingga masuk kedalam hutan rimba, sampai dataran tinggi dan puncak gunung yang akses jalannya sangat ekstrim.

Unsur alam sudah mengalir dalam tatanan kehidupan perempuan Dayak, bertahan hidup dengan situasi alam yang keras tidak menentu, walau alam bersahabat tetap waspada. Kedekatan perempuan Dayak dengan alam menjadikan mereka selalu mengamati gerak lembut perubahan alam, akibatnya perempuan Dayak semakin mampu menyatu dengan alam. Kebersamaan dengan alam dan keheningan menjadikan mereka mampu menyerap getaran alam. Kepekaan menjadi semakin terasah dan perlahan tapi pasti kemampuan spiritual dalam diri tumbuh dan berkembang. Pengaruh situasi alam tercermin dalam sikap dan gaya hidup perempuan Dayak yang selalu berhati-hati, tegas, tanpa basa-basi, langsung pada tujuan, tidak mudah terpengaruh, pekerja keras, dan berani menanggung risiko. Walaupun alam telah mendidik perempuan Dayak untuk berkarakter demikian, bukan berarti perempuan Dayak tidak memiliki kelembutan.

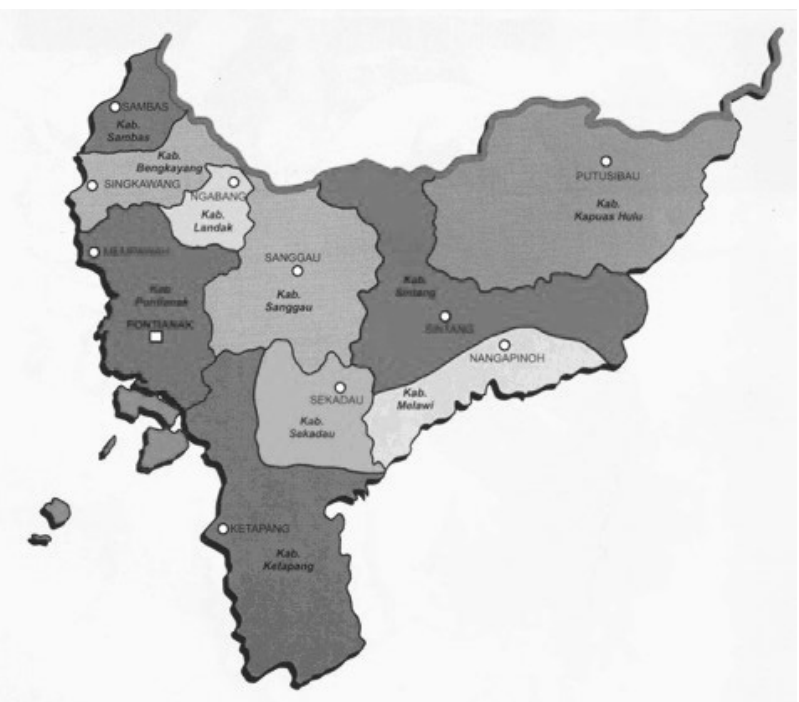

Gambar 1. Peta Kalimantan Barat dan Kabupaten-kabupaten Sumber: http://soaltescpns.info/wp-content/uploads/2014/10/ Hasil-CAT-CPNS-Kabupaten-Kubu-Raya-2014.gif (diakses pada1 Mei 2015, Pukul 14:26 WIB) 
Diamati dari hasil karya mereka misalnya anyam-anyaman, tenunan, tato, nyanyian, serta tarian, tergambarkan gabungan sifat gagah perkasa dan kelembutan perempuan Dayak.

Kalimantan Barat memiliki 151 subsuku Dayak dari 9 kabupaten (gambar 1). Dari itu semua, tiga Kabupaten dan empat subsuku Dayak menjadi pilihan subjek penciptaan karya ini, yakni suku Dayak Sungkung di Sanggau, Suku Dayak Desa di Sintang, dan Suku dayak Iban serta Kayan di Putussibau. Dipilihnya kabupaten-kabupaten dan suku-suku tersebut dikarenakan oleh masih ditemukannya perempuan Dayak yang melestarikan dan mempertahankan kebiasaan (tradisi) dalam kehidupan Dayak, yang berada di tengah serbuan kemajuan zaman yang serba canggih dan modern. Tantangan mereka pada generasi penerus yang hidup di era sekarang memiliki cara pemahaman yang berbeda, sehingga menganggap suatu hal yang pada zaman sebelumnya suatu tradisi itu penting menjadi tidak penting pada zaman generasi muda saat ini. Salah satu contoh tradisi khas pada kelompok perempuan orang Kayan yaitu memanjangkan daun telinga, bagi generasi terdahulu hal tersebut begitu penting dan sangat perlu dilakukan, tetapi pada zaman modern saat ini memanjangkan daun telinga merupakan hal yang memalukan dan menyakitkan bagi generasi sekarang.

Dengan banyaknya perubahan makna nilai kebudayaan pada kelompok perempuan Dayak, bisa saja nantinya perlahan tapi pasti mengubah karakter budaya Dayak bahkan menghilangkannya, sehingga membentuk suatu corak budaya baru di lingkungan masyarakat yang tumbuh dan bekembang dengan tata nilai yang disepakati oleh masyarakat Dayak sekarang ini. Potret kelompok perempuan-perempuan Dayak, dapat memberi satu cara pandang baru dan mungkin menjadi inspirasi bagi yang melihat dan merasakan, sehingga membuka matahati tentang lingkungan budaya di sekitaryang mulai pudar oleh arus kemajuan zaman.

Tujuan penciptaan ini adalah (1) Mengupas jati diri perempuan suku Dayak Kalimantan Barat melalui foto potret; (2) Memvisualisasikan identitas perempuan suku Dayak Kalimantan Barat dengan teknik potret; (3)Mengubah pemikiran masyarakat melalui medium foto mengenai perempuan Dayak yang tidak memiliki keterampilan dan terbelakang karena wilayah pemukimannya berada di pedalaman yang jauh dari perkotaan; dan (4)Mendokumentasikan sisa tradisi pada perempuan suku Dayak yang diperkirakan tradisi tersebut akan hilang karena tidak adanya pelaku / penerus.

\section{PEMBAHASAN}

\section{Foto Potret / Portrait}

Foto potret sering diartikan dengan pemotretan wajah manusia secara close-up dalam format setengah atau tiga perempat badan. Nugroho (2006:264) menjelaskan,

"Portrait berasal dari bahasa
latin "protahere" yang arti-
nya mengekspresikan ke
luar. Berarti foto potret
harus mampu menampilkan
karakter / ekspresi manusia
dengan situasi lingkungannya.
Artinya keberadaan lingkungan
juga berfungsi menonjolkan
karakter manusia tersebut.
Karakter tersebut bisa berasal
dari manusianya sendiri atau
manusia bersama lingkungan
dan peristiwa di sekitarnya."

Irwandi \& Apriyanto (2012: 5) menjelaskan, adapun unsur dalam foto potret adalah penonjolan kepribadian / personality, penggunaan pencahayaan efektif, latar belakang, dan pose subjek. Hal utama ialah penonjolan kepribadian yang didalamnya menampilkan karakter personal seseorang 
yang bersifat unik, karena karakter personal merupakan salah satu bagian dari identitas subjek dalam foto potret.sehingga menjadi pembeda fotografi potret dengan genre-genre fotografi lainnya.

\section{Dokumenter / Documentary}

Penciptaan karya ini termasuk dalam ranah fotografi dokumenter, karena foto dokumenter dapat menjadi salah satu media yang tepat dalam menyampaikan realita sosial. Dokumenter berasal dari kata "dokumen" yang artinya sesuatu yang tertulis atau tercetak, yang dapat dipakai sebagai bukti atau keterangan. Nugroho (2006: 104) menjelaskan foto dokumentasi dapat diartikan sebagai pengumpulan bukti-bukti atau keterangan mengenai suatu peristiwa melalui media foto. Tjilik Riwut (2003) mengungkapkan, "Informasi dan dokumentasi sejarah merupakansuatu peninggalan terbaik untuk anak bangsa, sesuatu yang dapat digunakan untuk kembali bercermin melihat awal dari keberadaan sekarang".

Foto dokumenter tidak terlepas dengan permasalahan sosial manusia yang setiap saat dan setiap waktu terus berubah dan berkembang. Sama halnya permasalahan dengan kebudayaan Dayak, yang juga merupakan aset budaya nusantara. Tata cara hidup suku Dayak terkesan tersimpan rapi dan hanya dikenal lingkungannya sendiri, kebiasaan di masa lalu, demi menjaga kesakralan tradisi rahasia suku adalah milik suku itu sendiri. Situasi demikian merupakan tantangan bagi masyarakat Dayak untuk lebih berani membuka diri dengan terciptanya karya potret ini dapat mengenalkan budaya serta adat-istiadatnya kepada dunia, khususnya bangsa sendiri. The Editor of Time-Life (1972: 9) menyebutkan, "Documentary Photography: a description of the real world by photographer whose intent is to communicate something of importance to make a comment, that will be understood by the viewer." (Fotografi Dokumenter: sebuah catatan dari sebuah kehidupan nyata oleh fotografer yang bermaksud mengkomunikasikan sesuatu yang dianggap penting untuk membuat sebuah komentar, yang akan dimengerti oleh penonton).

\section{Etnografi}

Tidak mudah untuk mengetahui identitas seperti apa yang ada pada perempuan Dayak khususnya Dayak Iban, Kayan, Desa, dan Sungkung. Metode etnografi menjadi salah satu cara untuk mengetahui bagaimana perempuan Dayak menjalankan kehidupan sehari-hari. Mereka rata-rata hidup berkelompok dalam satu rumah panjang yang isinya belasan bahkan dua puluhan kepala rumah tangga.

Etnografi merupakan pekerjaan mendeskripsikan suatu kebudayaan, dengan tujuan untuk memahami suatu pandangan hidup dari sudut pandang penduduk asli. Bronislaw Malinowski (1997: 4) mengemukakan, bahwa tujuan etnografi adalah memahami sudut pandang penduduk asli, hubungannya dengan kehidupan, untuk mendapatkan pandangannya mengenai dunianya. Penulis belajar mengenai kelompok perempuan Dayakyang telah belajar melihat, mendengar, berbicara, berpikir, dan bertindak dengan cara yang berbeda. Sehingga penulis tidak hanya mempelajari masyarakat tetapi belajar dari masyarakat.

Purnomo mengatakan pada katalog pameran "Perjalanan ke Tanah Leluhur" (2003), etnografi adalah cara mendeskripsikan secara rinci dan menganalisis tingkah laku manusia berdasarkan studi pengamatan di suatu tempat dalam kurun waktu cukup lama. Metode etnografi yang secara umum digunakan dalam membantu proses terciptanya potret perempuan Dayak, di jelaskan oleh Spradley (1997: 65) yaitu dengan cara mengumpulkan data berdasarkan pengamatan 
dan wawancara berikutnya analisa data, dan menulis. Paling utama adalah bagaimana menentukan informan. Informan merupakan pembicara asli, berbicara dalam bahasa atau dialeknya sendiri. Informan merupakan sumber informasi, sehingga dapat menjawab pertanyaan-pertanyaan mengenai kehidupan sehari-hari. Pertanyaan yang dilontarkan seperti, mempertanyakan alasan kewajiban perempuan Kayan memanjangkan daun telinga. Kemudian mengapa generasi muda tidak lagi mau memanjangkan daun telinga seperti generasi tua, padahal tradisi tersebut sudah menjadi identitas yang sangat terkenal di dunia. Setelah melakukan pengamatan, wawancara, mempelajari, dan memahami kehidupan perempuan Dayak berikutnya dengan mudah diketahui sifat masing-masing subjek yang akan divisulisasikan pada media potret.

\section{Semiotika}

Suku Dayak di dalam kehidupannya banyak sekali menggunakan simbol-simbol sebagai suatu media komunikasi, ungkapan ekspresi di kehidupan sosial yang terilhami dari alam.Koentjaraningrat (1990: 137-139) menjelaskan, bahwa agama asli suku Dayak adalah agama Kaharingan yang mempunyai arti "air kehidupan". Mempunyai kepercayaan bahwa alam sekitar hidupnya itu penuh dengan makhluk-makhluk halus dan ruh-ruh yang menempati tiang rumah, batu-batu besar, pohon-pohon besar, hutan belukar, air, serta alam sekeliling tempat tinggal manusia.

Kebersamaan dengan alam menyebabkan leluhur orang Dayak sangat memperhatikan dan selalu mengamati segala petanda alam disekitarnya. Contohnya petanda alam yang diketahui masyarakat Dayak mereka mampu membedakan bagaimana suara burung yang menunjukan kegembiraan (tertawa) dan suara burung menyatakan kesedihan dan menangis, tanda semua itu mempunyai pertanda (arti) tertentu bagi kehidupan. Alex (2003: 177) mengatakan:

"Begitu eratnya kebudayaan manusia dengan simbol-simbol, sampai manusia pun disebut makhluk dengan simbol-simbol. Manusia berpikir, berperasaan, dan bersikap dengan ungkapanungkapan yang simbolis. Masingmasing kebudayaan memberikan suatu cara untuk melihat dunia, kebudayaan memberi kategori simbol, tanda, dan juga mendefinisikan dunia tempat masyarakat itu hidup".

\section{Kebudayaan}

Kebudayaan merupakan fenomena yang selalu berubah sesuai dengan alam sekitarnya dan keperluan suatu kelompok. Wibowo (2007: 89) menjelaskan, kebudayaan adalah suatu corak hidup dari lingkungan masyarakat yang tumbuh dan berkembang berdasarkan spiritualitas dan tata nilai yang disepakati oleh suatu lingkungan masyarakat. Banyak hal yang bisa dipelajari dari kebudayaan Dayak khususnya pada Perempuan Iban, Kayan, Desa, dan Sungkung. Koenjaraningrat (1984: 2) menjelaskan isi kebudayaan adalah sistem religi, sosial masyarakat, sistem pengetahuan, bahasa, kesenian, mata pencaharian hidup, dan teknologi serta peralatan.

Permasalahan yang terjadi yakni berubahnya kebudayaan Dayak dari generasi tua ke generasi muda sekarang ini menjadikan hilangnya beberapa identitas Dayak itu sendiri. Hal ini mengakibatkan memudarnya rasa percaya diri pada generasi tua untuk mewariskan tradisinya kepada anak cucu.

\section{Ide dan Konsep Perwujudan}

Ide dan konsep perwujudan dalam penciptaan ini menceritakan identitas perempuan Dayak Iban, Kayan, Desa dan Sungkung menggunakan teknik potret dalam 
ranah dokumenter. Foto ini dibuat tanpa ada manipulasi gambar sesuai keadaan yang sebenarnya ke dalam sebuah karya potret, kemudian digunakan sebagai media komunikasi tentang karakter perempuan Dayak sesuai empat subsukunya tersebut. Soedjono (2006: 28-29) menjelaskan:

\begin{abstract}
"Karya fotografi dapat bermakna dokumentatif karena sifatnya yang dapat mengabadikan suatu objek atau peristiwa penting dengan kemampuan realitas dan detil visual yang memadai. Hasil reproduksinya yang tidak terbatas baik jumlah maupun ukurannya memungkinkan sebuah karya fotografi dapat disebarluaskan dan disimpan sebagai acuan referensi data dan informasi yang bisa dipercaya bagi kepentingan masa depan".
\end{abstract}

Foto potret merupakan sebuah rekaman visual yang lebih kuat menonjolkan subjek (tokoh) menjadi sumber informasinya. Elemen-elemen yang terkandung pada subyek yaitu raut wajah / ekspresi, pose (bahasa tubuh) yang menunjukkan sikap, profesi, status sosial, dan hubungan keluarga. Dari elemen-element tersebut akan diceritakan sosok perempuan Dayak secara personal dan berkarakter. Dari foto-foto yang dihasilkan tersebut selanjutnya dilakukan penyeleksian awal untuk memilih foto yang akan diajukan.

\section{Metode Penciptaan Karya}

Potret dokumenter akan memberikan kesan yang mendalam apabila fotografer dekat dengan objek dalam segala aktivitasnya. Interaksi yang baik antara fotografer dan objek berperan sangat penting, nantinya dapat terlihat dari foto yang dihasilkan.

Pelaksanaan pemotretan memakan waktu dua bulan dengan empat lokasi pemotretan. Dari tanggal 1 November s/d 30 Desember
2014, perjalanan dimulai dari Kota Pontianak - Kapuas Hulu - Sintang - Sanggau. Untuk berada di satu lokasi memakan waktu 5-6 hari bermalam. Dalam tahap ini dilakukan pencarian data dan informasi yang terkait dengan suku Dayak Iban, Kayan, Desa dan Sungkung. Untuk Dayak Kayan penulis sudah cukup mengenal dengan beberapa masyarakat Kayan karena sebelumnya pernah mengunjungi kampung tersebut kemudian untuk Dayak Iban di sungai utik, Dayak Desa, dan Dayak Sungkung menjadi pengalaman kali pertama pengunjungan. Pencarian data tertulis di kantor Balai Pengkajian Sejarah dan Pelestarian Kebudayaan di Kota Pontianak. Kemudian pencarian data tidak tertulis dilakukan dengan cara menemui narasumber yang pernah berkunjung ke kampung Dayak tersebut. Narasumber yang dikunjungi adalah mahasiswa pecinta alam yang beralamat di Base Camp Mapala "ARKHA" (Anak Rimba Khatulistiwa) Universitas Panca Bakti Pontianak. Mereka dapat memberikan saran serta informasi jalur perjalanan dan bagaimana karakter masyarakat Dayak. Setelah data awal cukup jelas sebagai bekal untuk mengenal dan mengunjungi kampung Dayak, tahap berikutnya adalah proses pendekatan dan pengamatan kepada masyarakat setempat. Setelah cukup mengenal satu sama lain dan tidak ada kecanggungan (keakraban) pada saat itulah memudahkan proses pemotretan dengan mengembangkan foto acuan.

Perlu dipersiapkan konsep pembuatan karya serta peralatan fotografi yang dibutuhkan dalam potret perempuan Dayak Iban, Kayan, Desa, dan Sungkung. Berikut sket konsep gambaran ide pemotretan. Sketsa hanya membantu dalam pengembangan ide, yang nantinya disesuaikan dengan keadaan sebenarnya di lokasi. 

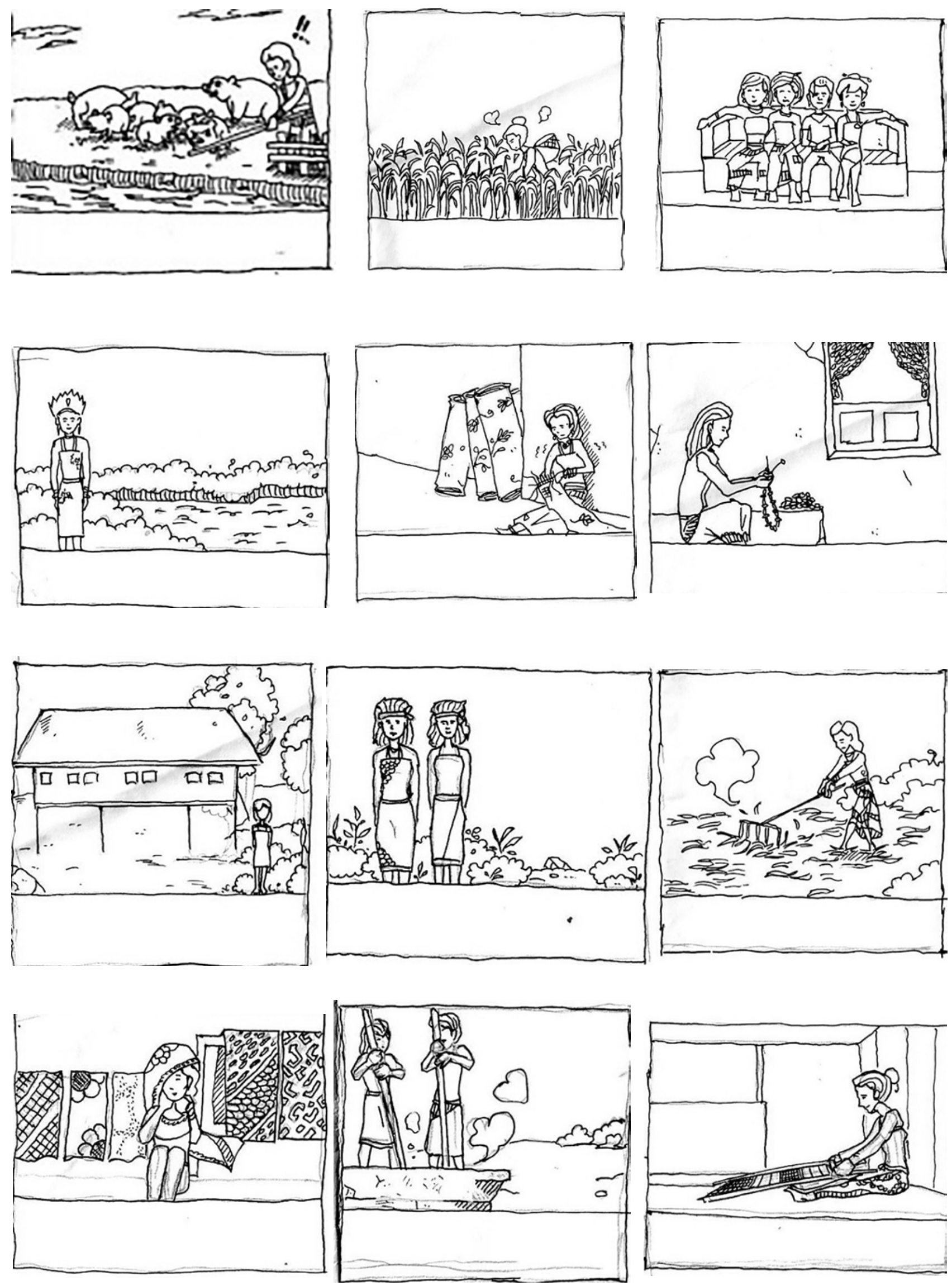

Gambar 2. Sketsa konsep sebelum pemotretan 


\section{PEMBAHASAN}

Menggulung tembakau (lihat gambar 1) di lembaran daun kering yang biasa disebut dengan rokok linting atau longlat. Aktivitas merokok merupakan suatu kebiasaan yang dilakukan oleh perempuan Kayan pada saat melakukan kegiatan harian seperti berladang, memasak, menganyam, dan bersantai. Tipung Ding bersantai menikmati waktu senja sore di teras rumah sambil mengunyah sirih atau "nginang" setelah itu biasanya diakhiri dengan menghisap rokok dari daun kering yang tembakaunya merupakan hasil dari ladang sendiri. Kehidupan Tipung Ding yang berkasta bangsawan tidak berbeda dengan kehidupan masyarakat di sekitar, karena zaman modern saat ini kasta-kasta Dayak Kayan tidak lagi mempunyai "tempat" (tidak lagi berlaku) mengenai peraturan kasta bangsawan serta status sosial pada simbol tato dan telinga panjang. Alasan pemahaman dan berbedanya fungsi suatu simbol tradisi masa lalu dan sekarang menjadikan hal tersebut tidak memiliki tempat di masyarakat. Saat ini Tipung Ding hidup sangat sederhana, apa adanya, serta ramah tamah saat bertemu dengan tetangga kampung maupun orang yang baru pertama di kenalinya. Sorotan mata yang tajam dengan guratan garis di wajahnya mengisyaratkan kekhawatiran akan perubahan bahkan hilang tradisi Dayak Kayan sesungguhnya. Dalam usianya yang hampir seabad, ia telah menyaksikan perubahanperubahan luar biasa, sejak zaman berkelana jauh di dalam hutan rimba hingga zaman modern dengan kemajuan teknologi sekarang ini.

Pemotretan dilakukan di teras rumah Tipug Ding. Foto ini memperlihatkan aktivitas harian Tipung Ding duduk di teras rumah sambil memperhatikan orang-orang berlalulalang di depan rumahnya. Rumah kayu menjadi background dan Seraung yang diletakkan diantara pintu serta keranjang anyaman yang merupakan tempat menyimpat

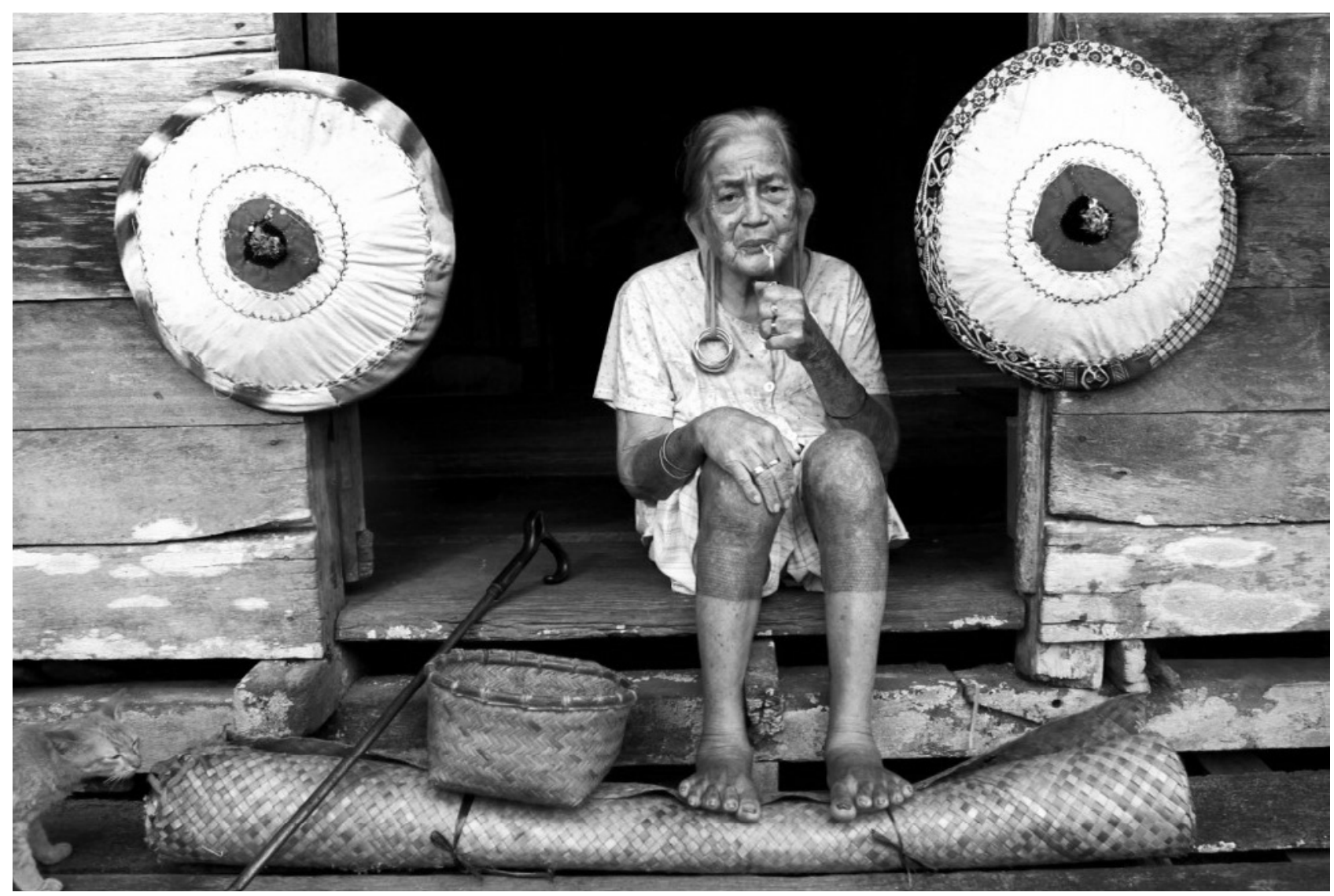

Gambar 3. "Rokok Linting”, Tanjung Durian, Putussibau (2015) Luster Paper $100 \mathrm{~cm}$ x 70cm 


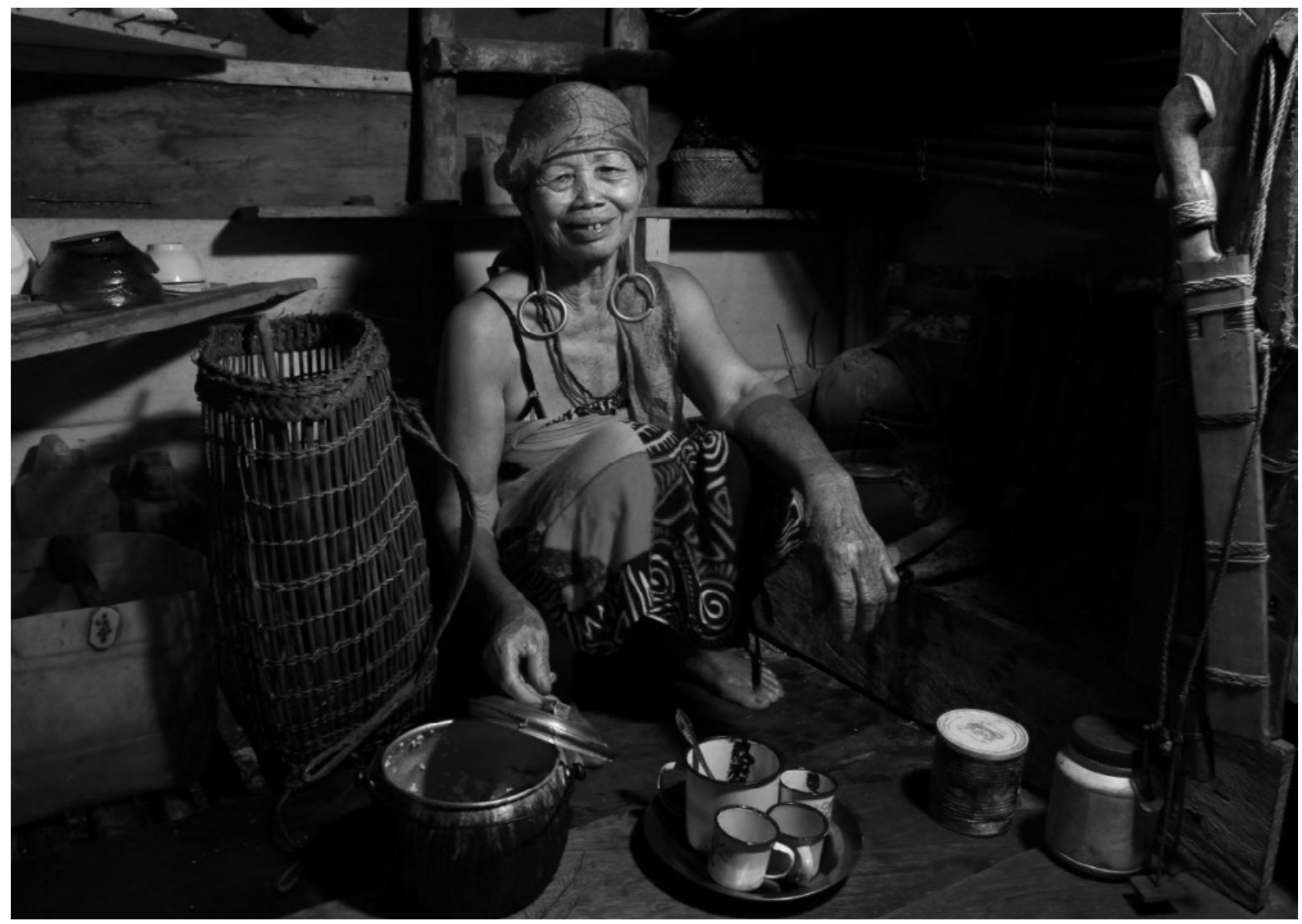

Gambar 4. "Pondok Ladang”, Tanjung Durian, Putussibau (2015) Luster Paper 100 x 70cm

bahan sirih, tikar anyam sebagai alas, dan tongkat merupakan peralatan yang setiap hari selalu ia gunakan. Properti tersebut menggambarkan kehidupan Tipung Ding dalam kesederhanaan walaupun ia seorang berketurunan raja.

Pose pemotretan pun tidak banyak variasi dan ekspresi kendala sakit kaki yang dialami Tipung Ding sehingga menjadikan ia tidak dapat melakukan aktivitas normal di luar rumah seperti masyarakat lainnya. Posisi tubuh duduk di depan pintu menghadap ke arah kamera/posisi en face serta menggunakan teknik long shot sehingga tampak secara keseluruhan suasana, properti yang selalu ia kenakan, dan terlihat tato pada betis yang merupakan motif yang menandakan kebangsawanannya.

Ekspresi alami ketika ia menyalakan rokok lintingnya merupakan momen yang pas, hal tersebut menunjukkan rokok sudah melekat dengan kehidupan perempuan- perempuan Kayan. Di sela pemotretan Tipung Ding mengatakan dalam bahasa Kayan yang bahasa Indonesia mempunyai arti "Saya masih mengharapkan ada orang-orang/masyarakat yang menyambung rumahnya ke rumah saya, sehingga menjadi rumah panjang seperti dulu". Rumah tunggal Tipung Ding sekarang ini masih memiliki bentuk-bentuk rumah panjang sehingga memudahkan masyarakat untuk menyambung bangunan bilik yang baru. Namun sampai saat ini belum ada masyarakat melaksanakan hal tersebut. Cahaya yang digunakan adalah memanfaatkan cahaya siang hari dengan fill-in light menggunakan lampu kilat yang di tambah dengan lightsphere membuat cahaya menjadi lembut.

Pondok ladang (lihat gambar 4) adalah sebutan rumah sementara pada saat melakukan pekerjaan berladang di hutan. Pemukiman masyarakat Kayan yang berada di tepi sungai mendalam menjadikan lokasi ladang-ladang jauh dari rumah. Rata-rata 
lokasi ladang berada di dalam hutan rimba, dengan jarak 1-2 jam menggunakan sampan mesin dari rumah menuju lokasi tempat bekerja. Alasan jarak yang cukup jauh sehingga terciptalah rumah pondok sebagai tempat berteduh jika tidak pulang ke rumah.

Perempuan Kayan rela bermalam di pondok ladang berminggu-minggu hingga berbulan-bulan dengan peralatan seadanya. Tanpa listrik hanya lampu minyak ditemani cahaya bulan, tanpa fasilitas kompor gas hanya kayu api sebagai penghangat, tanpa kamar mandi akan tetapi tersedia sungai jernih tanpa merkuri serta dihidangkan pemandangan sejuk hutan rimba. Dapur merupakan ruang utama di dalam pondok ini, walaupun sederhana di sinilah melahirkan kehangatan saat memasak, makan bersama, dan bercanda menikmati waktu istirahat malam panjang.

Biasanya perbekalan yang paling penting sebelum ke pondok ladang adalah membawa beras, kopi, gula, garam, biskuit, dan ikan kaleng dengan merk produk Malaysia. Untuk tambahan lauk-pauk biasanya langsung dapat dilokasi pondok ladang seperti mencari ikan di sungai dan tumbuh-tumbuhan sebagai sayuran (pakis dan jamur). Pengolahan bahan tersebut biasanya tanpa goreng dan tumis menggunakan minyak, semua bahan di kelola secara rebus.

Pemotretan di dalam ruangan tepatnya di depan perapian (dapur kecil) yang memiliki cahaya minim di waktu sore serta tidak ada aliran listrik di dalam hutan. Penggunaan satu buah lampu kilat dengan aksesoris lightsphere sangat membantu sebagai cahaya utama pemotretan di dalam ruangan minim cahaya. Hasil pencahayaan yang sedikit dramatis menunjukkan suasana asli ruangan di dalam pondok ladang yang cahayanya redup/remang-remang.

Banyak sekali barang-barang di dapur mini yang di manfaakan sebagai properti untuk melengkapi foto potret ini seperti tas keranjang yang biasa di gunakan untuk membawa hasil buruan dan kayu bakar, periuk nasi, cangkir kopi berbahan seng, mandau sebagai alat untuk memotong kayu yang merupakan senjata tradisional suku Dayak, kemudian rak peralatan makan (piring, mangkok) menjadi background pada foto ini. Sebenarnya penulis ingin memperlihatkan bentuk dapur tradisional yaitu tempat perapiannya namun kendala peralatan hanya mempunyai satu buah lampu kilat sehingga tidak dapat menerangi area perapian tersebut.

Posisi subjek menghadap ke arah kamera/en face dan gambar diambil secara long shot atau menyeluruh untuk memperlihatkan aktivitas subjek di depan perapian bersama peralatan dapurnya. Seharihari subjek mengenakan kain kemben ketika pulang istirahat di dalam pondok landang agar tubuhnya terasa sejuk.

Ekspresi senang dihiasi senyum di wajahnya saat tangan memegang tutup periuk agar tampak tato di tangan. Penggunaan kain di kepala untuk menyerap keringat saat ia beraktivitas kemudian terlihat aksesoris anting menggantung menghiasi telinga panjang yang terlihat cantik, hal tersebut merupakan identitas perempuan Kayan.

Dayak Sungkung (lihat gambar 5) identik dengan perempuan memakai gelang kuningan pada bagian di pergelangan tangan dan di

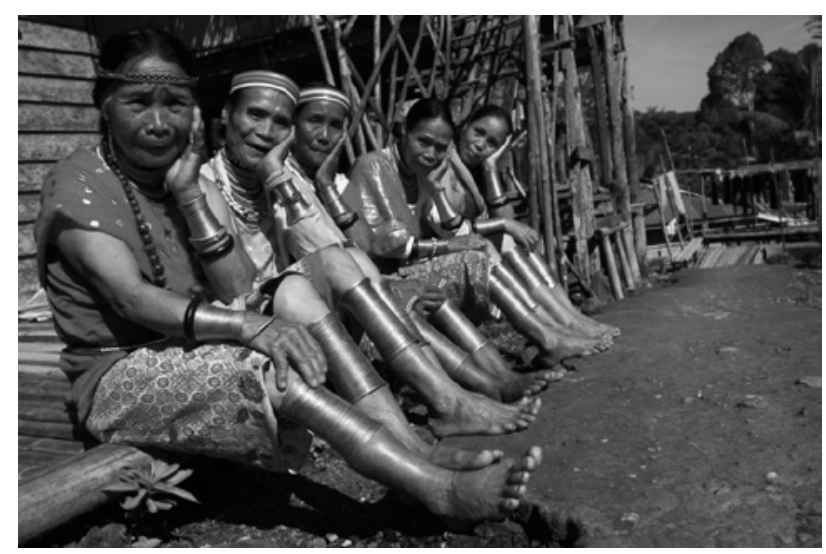

Gambar 5. "Perempuan Sungkung", Badat Lama, Entikong (2015) Luster Paper 100 x 70cm 
betis. Pemaknaan idenitas tersebut sebagai simbol status sosial keluarga terpandang dan kecantikan seorang perempuan Sungkung. Faktor keadaan alam di dataran tinggi juga menjadi alasan penggunaan gelang kuningan. Dahulu seorang ayah sangat sayang kepada anak perempuannya dihadiahkan berupa gelang kuningan sebagai tanda rasa kasih sayang, maka dibuatlah gelang tersebut hasil karya seni orang tua kepada anak permpuan. Selain menjadi nilai sebuah perhiasan yang menunjukkan sebagai keluarga terpandang, gelang kuningan juga berfungsi sebagai penompang tubuh agar kokoh dan seimbang saat berjalanan khususnya ketika membawa beban (barang).

Pemukiman diatas gunung menjadikan kampung Badat Lama melewati jalan yang turun-naik, pemukiman rumah-rumah tidak rata menjadikan bentuk posisi rumah-rumah seperti anak tangga. Bahkan medan jalan menuju ladang lada yang rata-rata lokasinya di lereng-lereng gunung hingga di atas gunung membutuhkan posisi badan yang seimbang untuk medan ekstrim.

Waktu pemotretan di pagi hari untuk mendapatkan cahaya yang baik seperti cahaya yang rata dan jatuh bayangan tidak mengenai wajah subjek. Cahaya matahari pagi yang cukup baik sehingga tidak memerlukan cahaya tambahan berupa lampu kilat atau external flash.

Komposisi dan jumlah subjek berupa group shot/pengambilan gambar sekelompok subjek. Lima perempuan Sungkung dipotret secara long shot tampak menyeluruh dari kepala hingga kaki dengan posisi wajah menghadap kamera/posisi en face. Teknik low angle menggunakan lensa sudut lebar mendekati kaki subjek menjadikan komposisi foto yang perspektif ingin menangkap detail gelang-gelang kuningan dan bentuk betisbetis yang mengecil.
Kostum yang digunakan merupakan pakaian keseharian mereka sehari-hari, agar tampak berbeda dan berwarna maka perlu arahan mengenai pakaian dengan tambahan selendang dan aksesoris di kepala. Arahan gaya dan ekspresi pun perlu dilakukan yaitu mengarahkan mereka untuk menatap ke kamera dihiasi senyuman dan tangan memegang dagu agar telihat pose yang bervariasi dan untuk menampakkan gelang-gelang kuningan di kedua pergelangan tangan mereka.

Kampung Badat Lama (lihat gambar 6) adalah daerah paling hulu di Kalimantan Barat yang terletak di Perbatasan Sarawak, Malaysia Timur. Dapat di katakan suku Dayak Sungkung juga membantu dalam menjaga patok wilayah perbatasan antara Indonesia dan Malaysia. Kampung Badat Lama terletak di ujung pulau Kalimantan, ibarat kata letaknya paling belakang tetapi sebenarnya Kampung Badat Lama merupakan "terasnya” Negara Republik Indonesia yang langsung berhubungan dengan luar Negeri.

Kurangnya perhatian pemerintah terhadap daerah-daerah perbatasan merupakan masalah yang tidak terselesaikan. Berbagai macam alasan sehingga daerah-daerah tersebut menjadi tidak berkembang dan terpuruk. Salah satu contoh permasalahan pendidikan, di Badat lama hanya memiliki satu bangunan sekolah dan hanya untuk Sekolah Dasar saja

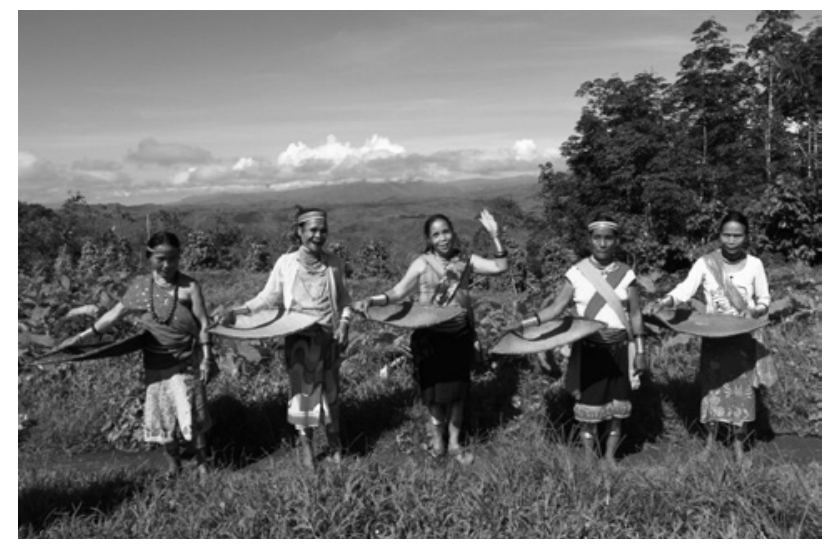

Gambar 6. Kampung di Atas Awan Badat Lama, Entikong (2015) Luster Paper $100 \times 70 \mathrm{~cm}$ 
mulai dari kelas 1 - 3. Melanjutkan sekolah jenjang berikutnya (kelas 4-6) anak-anak harus mendaftar sekolah kembali di kampung orang lain yaitu kampung Suruh Tembawang. Jarak kampung tersebut sangat jauh dengan medan berbukit dan berjalan kaki sehingga mengharuskan mereka tinggal di kampung Suruh Tembawang sampai hari libur tiba untuk kembali ke kampung halaman. Bagaimana nasib anak-anak Sungkung untuk melanjutkan SMP, SMA, dan perguruan tinggi. Saat ini hanya ada satu murid SMA dari Kampung Badat Lama yang terselesaikan sekolahnya.

Pemotretan menggunakan ruang tajam luas untuk memperlihatkan secara ke seluruhan subjek dan pemandangan alam. Background berupa pemandangan awan dan hutan-hutan membuktikan pemukiman orang Sungkung berada di atas gunung. Cahaya matahari yang sedikit mulai naik ke atas membuat bayangan menjadi tidak rata mengenai wajah pada subjek. Sehingga membutuhkan external flash dengan aksesoris tambahan yaitu lightsphere agar jatuhnya cahaya pada wajah subyek menjadi rata.

Group shot dapat mewakilkan gambaran masyarakat Sungkung yang pemukiman di atas puncak gunung kemudian pengambilan gambar secara long shot memperlihatkan kondisi suasana alam dengan hutan-hutan dan rerumputan hijau. Ekspresi wajah en face/menghadap kamera, dengan arahan gaya

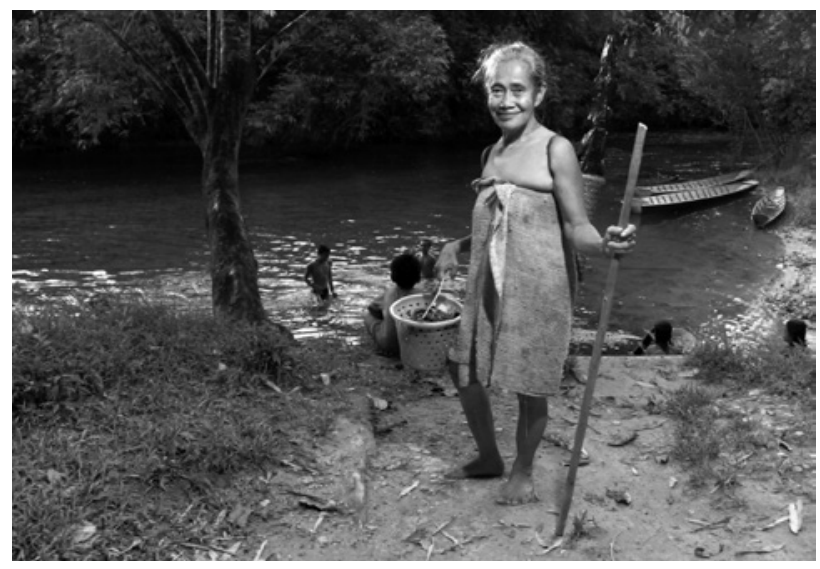

Karya Foto 19. “Mandi di Sungai”, Utik Kampung Sungai Utik, Embaloh Hulu (2015) Photo Paper Laminasi Doff 60 x $40 \mathrm{~cm}$ membuat senyum di wajahnya. Tersenyum untuk mendapatkan suasana senang, ada salah satu dari mereka yang tanpa diarahkan secara spontan berpose melabaikan tangan seakan-akan ia ingin memperkenalkan budayanya.

Properti yang digunakan adalah nampan anyaman yang biasa digunakan perempuan sungkung untuk mengambil sayur-sayuran ke hutan. Penggunaan properti tersebut menggambarkan aktivitas perempuan Sungkung yang biasa ke hutan bersama-sama mencari sayuran untuk lauk-pauk.

Banduang (65 tahun) merupakan salah satu warga Sungai Utik yang memanfaatkan air sungai dalam kehidupan sehari-hari (lihat karya 19) . Sungai Utik sangat berbeda dengan sungai-sungai lain karena sungai ini jauh dari limbah sampah dan jauh dari perkebunan sawit yang dapat merusak sanitasi air sungai. Sungai ini dapat terjaga dengan baik karena usaha masyarakat Dayak Iban dalam mempertahankan kelestarian alam hutan dan air sungai.

Masyarakat Dayak Iban menolak akan perusahaan-perusahaan sawit yang ingin mengambil lahan mereka untuk membuat perkebunan sawit di sekitar pemukiman Sungai Utik. Apai Janggut sebagai tetua adat mengatakan "Alam itu Ibu kami, alam yang memberikan kami makan, minum, dan udara. Jika alam dirusak, manusia akan bertahan hidup dengan apa? leluhur kita yang mengajarkan untuk menyayangi alam yang dititipkan Tuhan kepada manusia”. Keseriusan masyarakat Dayak Iban dalam menjaga hutan hingga akhirnya mendapat perhatian pemerintah pusat, buktinya pada 7 Agustus 2008 lalu Kampung Sungai Utik mendapat sertifikat Pengelolaan Hutan Lestari.

Pemotretan dilakukan pada saat Banduang hendak pergi mandi di sungai. Setiap sore pukul 16:00 Wib warga berdatangan ke 


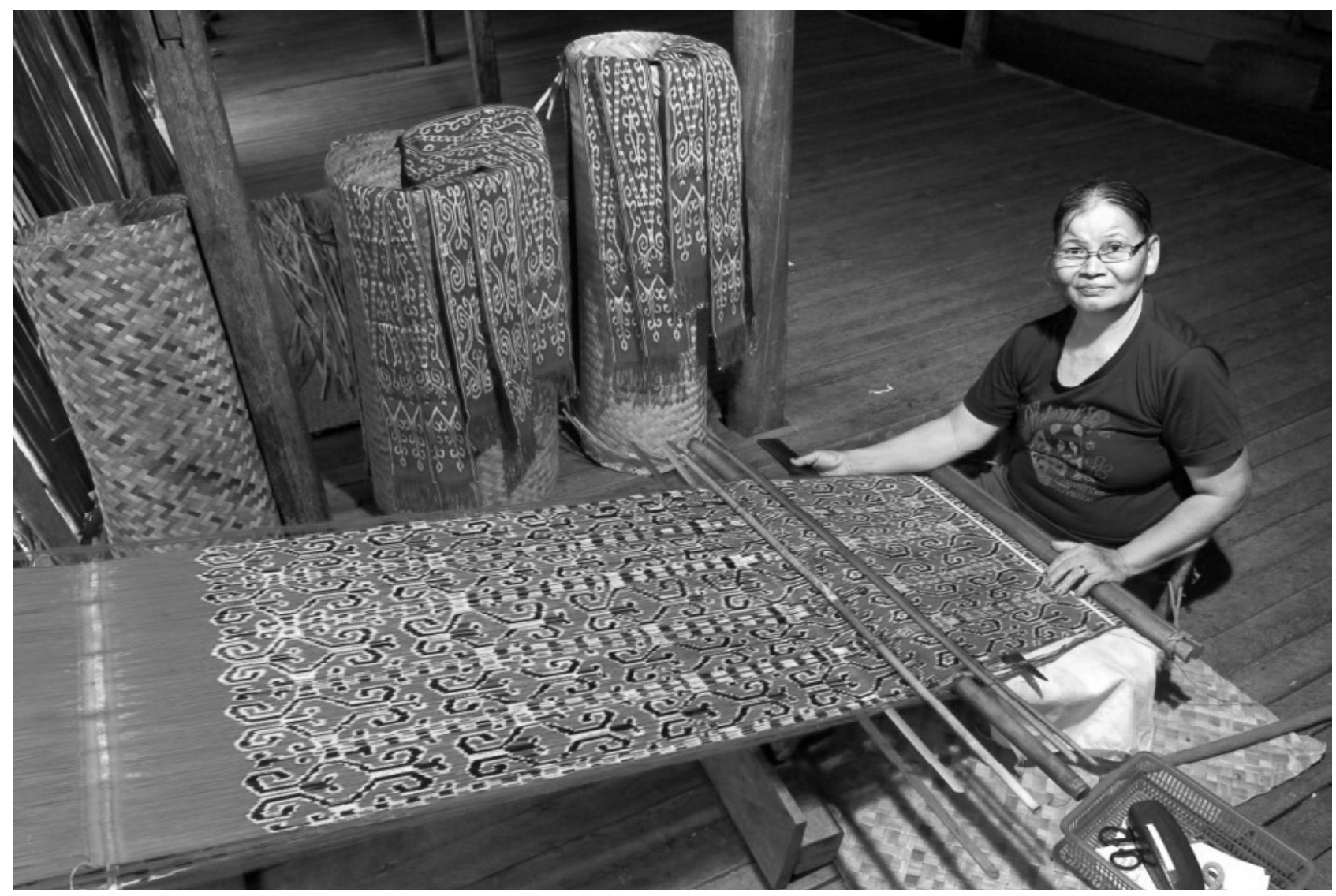

Karya Foto 23. Warisan Leluhur Dayak DesaEnsaid Panjang, Sintang (2015) Photo Paper, Laminasi Doff 60 x $40 \mathrm{~cm}$

sungai ini untuk mandi dan mencuci pakaian. Lokasi sungai yang berada di antara rimbunan pepohonan mendapatkan sedikit cahaya yang masuk ke dalam wilayah tersebut. External flash dengn aksesoris tambahan lightsphere membantu mengisi cahaya sebagai cahaya utama.

Long shot atau pemotretan secara menyeluruh untuk menunjukkan suasana masyarakat Iban pergi ke sungai untuk mandi dan mencuci pakaian. Tampak handuk terlihat usang melilit di tubuh Banduang yang sedang membawa ember kecil berisi peralatan mandi dan di belakang punggungnya terlihat tas keranjang (anjat) yang berisi pakaian untuk dicuci. Tangannya memegang tongkat kayu sebagai bantuan untuk menopang tubuhnya saat berjalan. Posisi wajah menghadap kamera/ en face dengan cahaya samping dari lampu kilat yang di posisikan sebelah kanan subjek.

Suasana sungai terlihat asri dihiasi hutan-hutan hijau, tampak beberapa orang sedang mandi kemudian di pinggir sungai terlihat sampan-sampan bersandar menjadi background foto potret Banduang yang hendak turun ke sungai.

Puna (57 tahun) menyelesaikan kain tenun (lihat karya foto 23) berukuran lumayan besar dengan menggunakan motif Sandung Cecak berwarna merah, hitam, dan putih (lihat karya 23). Butuh waktu 3 sampai 6 bulan untuk menyelesaikan 1 lembar kain berukuran lumayan besar. Sejak berumur 15 tahun perempuan Dayak Desa sudah mempelajari proses menenun dan membuat motif. Keahlian menenun merupakan sebuah kewajiban bagi perempuan Dayak Desa yang menjadi sebuah tradisi turun menurun yang melahirkan identitas Dayak Desa di Sintang.

Tenun ikat Dayak nyaris punah di karenakan tidak ada orang yang memberikan perhatian pada keberadaan tenun ikat tersebut. Terutama persoalan perubahan sosial dan ekonomi pada masyarakat Dayak yang terjadinya perubahan kebudayaan termasuk budaya menenun secara tradisional. Ada yang 
beranggapan menenun merupakan kegiatan masyarakat primitif dan terbelakang, pada akhirnya masyarakat Dayak menjadi kehilangan kebanggaan terhadap tradisi mereka.

Berlomba dengan era modern saat ini di ruai/balai-balai rumah betang di Sintang, perempuan-perempuan berkumpul dan melakukan kegiatan menenun. Perempuan Dayak Desa beranggapan bila tenun ikat punah maka eksistensi Dayak Desa pun hilang, dengan bantuan yayasan nonpemerintah, pemerintah setempat, dan organisasi lainnya yang mendukung pelestarian tenun ikat Dayak Desa hingga kini warisan leluhur tersebut tetap terjaga.

Menenun menjadi mata pencaharian masyarakat Dayak Desa, Puna mengatakan "Selain sebagai kebutuhan adat, menenun juga menjadi pekerjaan utama kami untuk mencari uang tambahan dalam memenuhi kebutuhan sehari-hari, jika kami mengandalkan uang suami saja akan tidak cukup". Adapun harga kain tenun dari ukuran syal hingga kain yang cukup besar mulai dari 25.000, 300.000, 750.000, dan 1.000.000 ke atas dengan hasil kain tenun ikat terbaik. Sembai (Kepala Dusun) menjelaskan "Kini tenun ikat Dayak Desa sudah diminati negara-negara luar dan diekspor ke beberapa negara terutama negara tetangga sangat dihargai di mancanegara. Salah satu buktinya dengan di pajangnya beberapa kain tenun ikat Sintang di Museum Tropem Belanda”.

Penggunaan warna kain tenun ikat Dayak Desa pada mulanya hanya berasal dari alam. Seperti memanfaatkan daun, akar, batang, kulit, buah, umbi, dan biji dari tumbuh-tumbuhan. Kemudian ada juga yang menggunakan pewarna dari binatang misalkan lemak ular dan labilabi, namun sekarang ini sudah banyak menggunakan pewarna sintetis (pewarna khusus tekstil) yang hasilnya lebih bagus dan hasil warnanya lebih segar atau "cerah" dibanding pewarna alami (alam).

Terdapat perbedaan antara tenun ikat Dayak asli dengan jenis kain tenun ikat sekarang ini yang banyak diproduksi menggunakan benang (bahan jadi) dan zat pewarna kimia. Hal ini menyebabkan beberapa proses yang mengandung nilai ritual bagi sebuah tenun ikat tidak lagi dilaksanakan. Sehingga terdapat perbedaan antara kain besuoh yang berarti kain masak dengan kain mata'. Kain masak yaitu pada proses pembuatannya dilakukan secara lengkap dan telah memenuhi persyaratan adat. Sedangkan kain mata' yaitu kain yang tanpa melewati persyaratan adat.

Pemotretan menggunakan properti hasil tenun ikat berupa syal-syal yang disusun diatas gulungan tikar agar komposisi terlihat menarik sebagai background. kemudian menggunakan external flash sebagai cahaya utama yang diposisikan di atas subjek dan sedikit menyamping. Posisi wajah menghadap kamera/en face dan pose tubuh sedang menenun yang pengambilan gambar subjek secara long shot.

\section{SIMPULAN}

Penciptaan karya foto "Potret Perempuan Dayak Iban, Kayan, Desa, dan Sungkung Di Kalimantan Barat" telah berhasil menghasilkan 25 karya foto potret perempuan-perempuan dari empat subsuku Dayak, namun masih banyak kekurangan pada karya-karya ini yang sebenarnya masih dapat dieksplorasilebih dalam mengenai potret suku Dayak. Masingmasing karya foto potret ini membawa identitas kesukuan pada diri mereka sendiri "inilah aku" sehingga memberikan informasi mengenai tradisi budaya Dayak sesuai subsukunya. Karya potret tersebut dapat bermanfaat sebagai dokumen sejarah budaya Dayak yang nantinya generasi terakhir sudah tidak 
dapat dilihat secara nyata dan hanya bisa disaksikan oleh bukti dari media fotografi.

Karya foto potret ini merekam perempuan Dayak sebagai subjeknya yang memiliki simbolsimbol kesukuan Dayak dan kegiatan harian perempuan-perempuan Dayak di pedalaman. Foto potret ini dibuat dengan memunculkan karakter personal subjek sehingga terbacalah identitas yang dimiliki subjek. Foto potret "Perempuan Dayak" adalah foto Potret dokumenter yang merekam kondisi atau situasi yang sebenarnya, akan tetapi pada foto potret diperlukan pengaturan subjek agar terlihat lebih baik, seperti pengaturan cahaya, latarbelakang, kostum, properti pendukung, pose dan ekspresi, dengan catatan tidak megubah karakter yang di miliki subjek.

Suku Dayak di pedalaman menjadi subjek dalam sebuah foto yang harus melewati medan yang jauh seperti gunung dan sungai, untuk menelusurinya diperlukan persiapan yang matang. Kondisi fisik yang prima serta pengetahuan informasi daerah tujuan yang lengkap. Peralatan fotografi harus dipersiapkan dan dilindungi secar sedemikian rupa sehingga aman dibawa pada saat menyusuri sungai.

Pada penciptaan karya seni ini diperlukan pengetahuan umum tentang bagaimana karakter masyarakat Suku Dayak dan perihal lain yang mendukungnya agar memperkaya penciptaan karya fotografi potret. Teknik pencahayaan selain cahaya alami juga menggunakan cahaya tambahan berupa lampu kilat untuk memunculkan karakter subjek. Artistik sebuah karya fotografi ditampilkan dalam tata cahaya dan komposisi gambar.

Beberapa kendala yang di alami selama pembuatan karya fotografi potret diantaranya biaya transportasi yang cukup tinggi, cuaca yang tidak tepat (musim hujan), dan minimnya menguasai bahasa lokal setempat. Mayoritas subjek foto potret ini adalah perempuanperempuan yang sudah lanjut usia yang masih memiliki sisa identitas kesukuan mereka, sehingga sulit untuk berkomunikasi karena pada orang tua hanya menggunakan bahasa daerah mereka sendiri. Kendala pada saat pengaturan pose serta ekspresi disebabkan orang-orang sudah lanjut usia ini jarang sekali mempunyai pengalaman di foto, pada saat pemotretan hampir semua ekspresi mereka berdiri lurus, akan tetapi sebagai fotografer mengusahakan membawa subjek untuk merasa nyaman dan santai pada saat di foto.

Budaya merupakan identitas suatu bangsa, suku dayak memiliki identitas yang sangat khas terutama pada perempuan, seperti tato, telinga panjang, penggunaan gelang kuningan, tenun, dan anyaman. Simbolsimbol tersebut merupakan bentuk karakter masyarakat yang dipengaruhi oleh keadaan alam tempat mereka tinggal.

Suku Dayak di pedalaman terlihat primitif dan menakutkan, tidak banyak orang untuk mengetahui serta mempelajari kebudayaannya sendiri serta menganggap kebudayaan leluhur adalah tahayul dan kolot. Jika mengenal lebih dekat bahwa tradisi leluhur memiliki kandungan arti dan nasihat-nasihat untuk kebaikan masyarakatnya. Suku Dayak adalah harta warisan budaya leluhur yang tidak dapat tergantikan dan tidak ditemukan di manapun kecuali di tanah Borneo, Indonesia.

Pedalaman suatu perjalanan yang cukup jauh, masuk ke dalam hutan, menyusuri sungai, dan mendaki bukit terlihat melelahkan dan menyeramkan, tetapi di dalamnya tersimpan harta tradisi di masa lalu yang indah, melalui fotografi potret hal tersebut dapat divisualisasikan.

\section{KEPUSTAKAAN}

Ajidarma, Seno Gumira., Kisah Mata Fotografi antara Dua Subyek: Perbincangan tentang Ada, Terbitan Galang Press, 2002.

Alex, Sobur. Semiotika Komunikasi, Bandung: PT. Remaja Rosdakarya, 2003. 
Alloy, S.; Albertus dan Istiani, C., Mozaik Dayak Keberagaman Subsuku dan Bahasa Dayak di Kalimantan Barat, Pontianak: Institut Dayakologi, 2008 Busselle, Michael. The Story of Photography, Terbitan Chancellor Press, 1992.

Christomy, T \& Yuwono, U., Semiotika Budaya, Depok: Pusat Penelitian Kemasyarakatan \& Budaya, 2004.

Dayakologi, Institut. Kebudayaan Dayak Aktualisasi dan Transformasi, Jakarta: PT.Gramedia Widiasarana Indonesia, 1994.

Hermanu. Borneo 1843, Yogyakarta: Bentara Budaya, 2010.

Herusatoto, Budiono, Simbolisme dalam Budaya Jawa, Yogyakarta: PT. Haninditia, 1984.

Irwandi dan Apriyanto, M. F. Membaca Fotografi Potret Teori, Wacana, dan Praktik, Yogyakarta: Gama Media, 2012

Koentjaraningrat, Kebudayaan Mentalitas dan Pembangunan, Jakarta: PT.Gramedia, 1984.

Koentjaraningrat, Manusia dan Kebudayaan di Indonesia, Jakarta: Djambatan, 1990,

Leonardus, Agus. S \& Tim Penyusun. Soedjai Kartasasmita Di belantara Fotografi Indonesia, BP ISI Yogyakarta LPP Yogyakarta, 2008.

Nugroho, R. A, Kamus Fotografi, Yogyakarta: Penerbit Andi, 2006.

Poerwanto, Hari. Kebudayaan dan Lingkungan dalam Perspektif Antropologi, Yogyakarta: Pustaka Pelajar, 2000.

Riwut, Nila, Bawin Dayak : Kedudukan, Fungsi, dan Peran Perempuan Dayak, Yogyakarta: NR Publishing, 2014.

Soelarko, R. M. Pengantar Foto Jurnalistik, Terbitan PT. Karya Nusantara, 1985.

Spradley, James P. Metode Etnografi, Yogyakarta: Tiara Wacana Yogya, 1997.

Stewart, Ian C., Indonesia Manusia dan Masyarakatnya, Indonesia: PT. Pranawajati, 1987.

Sudjiman, P dan Zoest, A. F. Serba-Serbi Semiotika, Terbitan: Gramedia Pustaka Utama, 1992.

Soedjono, Soeprapto, Pot - Pourri, Jakarta: Universitas Trisakti, 2006
The Editor of Time-Life. "Documentary Photography" Life Library Of Photography, New York, 1972.

Tim Penyusun Kamus Besar Bahasa Indonesia. Kamus Bahasa Indonesia edisi ke Tiga, Jakarta: Pusat Bahasa Departemen Pendidikan Nasional, 2008

Wibowo, Fred. Kebudayaan Menggugat Menuntut Perubahan atas Sikap, Perilaku, serta Sistem yang Tidak Berkebudayaan, Yogyakarta: Pinus Book Publish, 2007.

Zaitun, Subhan. Membina Keluarga Sakinah, Yogyakarta: Pustaka Pesantren, 2004.

\section{Artikel / Katalog}

Majalah Nasional Geographic, Edisi 26 Januari 2014.

Purnomo, Hadi, Katalog Pameran Foto "Perjalanan ke Tanah Leluhur", Terbitan Galeri Foto Jurnalistik Antara, 2003.

\section{Pustaka Laman}

agrobuti.net (diakses 1 Mei 2015, Pukul 17:00 Wib)

betungkerihun.dephut.go.id (diakses 1 Mei 2015, pukul 15:00 Wib)

coolephotography.co.uk (diakses Minggu, 26 April 2015, Pukul 15:20 wib)

folksdayak.wordpress.com (diakses 26 April 2015 Pukul 16:15 wib)

fysindonesia.files.wordpress.com (diakses 1 mei 2015, Pukul 14:08 Wib)

pinterest.com (diakses Minggu, 26 April 2015 Pukul 13.00 wib)

prosumis.com (diakses 1 Mei 2015, pukul 14:11 Wib)

soaltescpns.info (diakses 1 Mei 2015, Pukul 14:26)

suarapakat.blogspot.com (diakses 1 mei 2015, Pukul 16:00 Wib)

thetravelphotographer.blogspot.com (diakses 11 september 2014, Pukul 22:19 wib) 